\title{
Differences in the Level and Structure of Household Indebtedness in the EU Countries
}

\author{
Paulina Anioła, Zbigniew Gołaś
}

\begin{abstract}
The article presents the outcomes of dynamic, cross-section analysis of the differences in the level and structure of household indebtedness in EU countries and the range of problems with debt service between 2005 and 2009. Statistical data from of the EU Commission, obtained in the periodic research of people's incomes and living conditions (EU-SILC) and the ECRI - European Credit Research Institute, was used in the research, as well as the method of multi-dimensional analysis (cluster analysis and k-means method), enabling to classify EU households according to the features of their indebtedness. Moreover, in order to define the quantitative relationships between the level and structure of households' indebtedness and the frequency of repayment problems, tools such as correlation analysis and stepwise regression, enabling the description of its strength and direction of influence of selected variables on repayment problems.
\end{abstract}

KEY WORDS: $\quad$ indebtedness, debt structure, repayment problems, households, European Union

JEL Classification: D10, D14

1 Poznań University of Life Science, POLAND

\section{Introduction}

It is possible to notice that there has been a substantial rise in households' indebtedness in the EU over the last several years, measured as different categories, both in absolute terms and as a share in incomes and GDP (Lilico, 2010). A rise of household indebtedness measured as a ratio of debt to disposable income is especially common in advanced economies (Bloxham \& Kent, 2009). Credits enable households to sustain the consumption growth, simultaneously leading to the decline in household saving rate (Barba \& Pivetti, 2009).

The very phenomenon of households becoming indebted is natural and common in developed coun-

Corespondence concerning to this article should be addressed to: aniola@up.poznan.pl tries with modern financial systems. Over the last decades the attitude to a credit has changed and it has become a part of a modern consumer society (Lea, Webley \& Walker, 1995). Households accustomed to live on credit, and they treat it as an ordinary resource in a household economy (Raijas, Lehtinen \& Leskinen 2010). According to Dynan (2009) the increase in household borrowing had widespread gradually over the time across different demographic groups. The median of debt-to-income ratio had risen for all demographic groups (taking into account factors such as: age, education, income, housing tenure). A distinction should therefore be made between two notions: indebtedness and over-indebtedness (Russell, Maître \& Donnelly, 2011).

Joyce (2003) defined indebtedness as "a commitment to repay moneys which a debtor has borrowed and used" (as cited in Law Reform Commission, 2009, 

A non-hierarchical method of clustering, i.e. the kmeans method, was used in the research of the level and structure and problems connected with debt service among households. The clusters are generally formed in order to minimize inside-group variance and maximize the variance between groups. In other words, the aim of the method is to form homogeneous groups, minimizing the variance in clusters and maximizing the variance among them (Stanisz, 2007). Moreover, the tools of analyzing correlation and regression were used in the study in order to identify the strength and directions of the relationships among the features describing the studied phenomenon.

\section{The level of households' indebtedness in $\mathrm{EU}$ countries}

One of the basic ratios used in the comparative analysis of households' indebtedness level among countries is the quotient of households' credit indebtedness and their disposable incomes (Lilico, 2010). The values and dynamics of this ratio for particular EU countries between 2005 and 2009 are presented in Table 1. The data shows that households' indebtedness level in the EU measured as the share of the amount of indebtedness in disposable incomes has been growing steadily.

Between 2005 and 2009, the average annual increase of the ratio in the whole European Union amounted to nearly $5 \%$ and it was only in two countries, Ireland and Austria, that it remained stable. Germany was the only country where the share of credit indebtedness in disposable income declined steadily. The annual average pace of changes in households between 2005 and 2009 amounted to $-2.3 \%$.

It was in as many as six countries, including Denmark, Ireland, Spain, the Netherlands, Sweden and Great Britain, that the level of credit indebtedness exceeded households' disposable incomes greatly (>100\%). In 2006 Portugal joined the group (104.8\%). At the same, it needs to be stressed that the average level of households' credit indebtedness in the whole EU constituted $80 \%$ of households' disposable incomes while it nearly reached the value of disposable incomes in 2009 (amounting to 96.9\%). The most heavily indebted countries in the studied period were Denmark and the Netherlands. In Denmark, credit indebtedness exceeded disposable incomes by far more than $200 \%$ (232-282\%), and in the Netherlands, the proportion amounted to $176-200 \%$.

The greatest dynamics of growth between 2005 and 2009 as regards the mentioned proportion could be observed in households in Romania, Poland and Lithuania. The annual average proportion of households' debt in their disposable incomes was subject to a steady growth by approximately $25 \%$. However, these countries were also characterized by relatively low proportions of indebtedness to incomes. In spite of the dynamics, indebtedness constituted only $33,3 \%$ of disposable incomes in Romania, which was the lowest value in the whole European Union. Indebtedness rates in Slovenia and Slovakia reached similar levels. These countries were, however, characterized by a much slower rate of credit debt increase compared to incomes. Credit indebtedness in Poland and Lithuania did not, in turn, exceed a half of households' disposable incomes during the whole studied period. However, as it has been stressed before, the dynamics of the changes in those two countries was really high. The indebtedness of Polish and Lithuanian households had more than doubled in proportion to incomes, which was five times faster a pace than in the EU on average.

To sum up, the quoted data unequivocally shows that there are considerable discrepancies among EU countries as regards the level of households' indebtedness and the dynamics of its changes. The households of the 'old' EU countries are generally more indebted, but their indebtedness increases more slowly. The households in Central and Eastern Europe or countries which accessed the EU after 2004 are, in turn, less indebted, but the dynamics of the changes resulting into a greater degree of indebtedness is much higher. It mainly results from the differences caused by tradition and the level of development of financial markets. Other causes include income conditionings, financial awareness in a given society and the hitherto model of households' functioning in totally different social and economic systems.

\section{The structure of households' indebt- edness in EU countries}

Households' indebtedness should also be analyzed from the perspective of its typological structure, i.e. loans and mortgages indebtedness, indebtedness due to other obligations. 
Table 1. The level and dynamics of the quotient of households' credit indebtedness and disposable incomes in the EU between 2005 and 2009 (\%)

\begin{tabular}{|c|c|c|c|c|c|c|}
\hline Country ${ }^{a}$ & 2005 & 2006 & 2007 & 2008 & 2009 & $\begin{array}{c}\text { Annual average dynamics } \\
\text { of changes }\end{array}$ \\
\hline BE & 73.8 & 77.6 & 81.2 & 83.5 & 86.3 & 4.0 \\
\hline BG & 28.7 & 34.1 & 46.1 & 50.8 & 51.8 & 15.9 \\
\hline$C Z$ & 26.5 & 31.8 & 39.0 & 43.6 & 47.4 & 15.6 \\
\hline DK & 232.0 & 251.8 & 272.7 & 277.5 & 282.8 & 5.1 \\
\hline $\mathrm{DE}$ & 91.6 & 89.7 & 86.9 & 84.1 & 83.6 & -2.3 \\
\hline $\mathrm{EE}$ & 54.1 & 73.5 & 81.9 & 84.5 & 92.0 & 14.2 \\
\hline $\mathrm{IE}$ & 141.8 & 153.6 & 159.5 & 141.8 & 141.8 & 0.0 \\
\hline EL & 49.3 & 57.8 & 62.4 & 68.4 & 67.4 & 8.1 \\
\hline ES & 104.5 & 117.7 & 124.6 & 123.1 & 120.8 & 3.7 \\
\hline$F R$ & 61.5 & 65.4 & 68.8 & 70.4 & 71.6 & 3.9 \\
\hline IT & 42.4 & 45.4 & 48.1 & 47.7 & 50.0 & 4.2 \\
\hline LV & 47.8 & 68.6 & 77.7 & 68.6 & 68.5 & 9.4 \\
\hline LT & 20.0 & 29.6 & 41.9 & 42.8 & 47.5 & 24.1 \\
\hline $\mathrm{HU}$ & 28.7 & 33.9 & 40.3 & 51.2 & 52.5 & 16.3 \\
\hline $\mathrm{NL}$ & 176.9 & 188.0 & 188.3 & 194.2 & 199.8 & 3.1 \\
\hline AT & 68.3 & 67.5 & 68.2 & 68.9 & 68.3 & 0.0 \\
\hline$P L$ & 20.5 & 26.1 & 33.7 & 45.4 & 48.7 & 24.1 \\
\hline PT & 94.4 & 104.8 & 113.0 & 112.3 & 116.8 & 5.5 \\
\hline $\mathrm{RO}$ & 11.7 & 19.6 & 26.5 & 29.1 & 32.3 & 28.9 \\
\hline $\mathrm{SI}$ & 22.7 & 27.3 & 31.9 & 33.6 & 36.5 & 12.6 \\
\hline SK & 20.4 & 26.3 & 27.9 & 32.7 & 35.5 & 14.9 \\
\hline $\mathrm{Fl}$ & 78.3 & 84.7 & 88.6 & 90.3 & 92.7 & 4.3 \\
\hline SE & 115.2 & 122.9 & 127.4 & 130.8 & 139.1 & 4.8 \\
\hline UK & 148.4 & 157.6 & 166.4 & 165.1 & 164.9 & 2.7 \\
\hline EU & 80.0 & 84.7 & 89.2 & 93.8 & 96.9 & 4.9 \\
\hline
\end{tabular}

aBE-Belgium, BG-Bulgaria, CZ-Czech Republic, DK-Denmark, DE-Germany, EE-Estonia, IE-Ireland, EL-Greece, ES-Spain, FRFrance, IT-Italy, LV-Latvia, LT-Lithuania, HU-Hungary, NL-the Netherlands, AT-Austria, PL-Poland, PT-Portugal, RO-Romania, SI-Slovenia, SK-Slovakia, FI-Finland, SE-Sweden, UK- Great Britain, EU-the European Union 
Credits and loans taken out for accommodation reasons, including the purchase, maintenance and repair of people's places of residence, constitute the greatest part of households' indebtedness in EU countries.

The proportion of the volume of mortgages to households' disposable incomes and also their share in the general structure of indebtedness as well as the dynamics of changes of both ratios are presented in Table 2. Their analysis shows that there has been a steady increase of mortgages, both in relation to the level of disposable incomes and to the total level of indebtedness. It can be noticed that the proportion of average indebtedness due to mortgages to total incomes in the European Union amounted to 50\% in 2005.

However, it nearly reached $70 \%$ within the next five years. This means that the level of all charges for households' incomes increased substantially in the studied period. The increasing meaning of this type of obligations is reflected in the changes of the general structure of indebtedness. Between 2005 and 2009, the share of mortgages in the total value of credits increased in the EU from $66 \%$ to $70 \%$. The countries in which the share was the highest period of 2005-2009, the share all the time exceeded $80 \%$.

The ratio of mortgage burden to disposable incomes increased in all EU countries. Household in Germany were an exception here. Polish households, in turn, were characterized by the highest dynamics of changes. The average annual pace of changes in the proportion of mortgages to incomes in Poland amounted to 35\%. Romania, Slovenia, Lithuania and Bulgaria were also characterized by a vast dynamics of this ratio. The analyzed proportion increased by $25 \%$ in these countries. However, in spite of the high dynamics of growth, apart from Lithuania, mortgages and flat loans still constituted a relatively low percentage of all debts.

Table 2. Households' indebtedness due to flat loans and mortgages in EU countries between 2005 and $2009(\%)^{\mathrm{a}}$

\begin{tabular}{|c|c|c|c|c|c|c|c|c|c|c|c|c|}
\hline \multirow[t]{2}{*}{ Country ${ }^{b}$} & \multicolumn{2}{|c|}{2005} & \multicolumn{2}{|c|}{2006} & \multicolumn{2}{|c|}{2007} & \multicolumn{2}{|c|}{2008} & \multicolumn{2}{|c|}{2009} & \multicolumn{2}{|c|}{ average annual change } \\
\hline & । & $\|$ & । & $\|$ & 1 & $\|$ & I & $\|$ & I & $\|$ & । & $\|$ \\
\hline $\mathrm{BE}$ & 54.2 & 73.4 & 57.9 & 74.6 & 61.6 & 75.9 & 63.5 & 76.0 & 66.6 & 77.2 & 5.3 & 1.2 \\
\hline$B G$ & 8.1 & 28.2 & 12.9 & 37.8 & 18.8 & 40.8 & 21.7 & 42.7 & 22.7 & 43.8 & 29.4 & 11.6 \\
\hline$C Z$ & 18.4 & 69.4 & 22.7 & 71.4 & 28.8 & 73.8 & 28.5 & 65.4 & 33.2 & 70.0 & 15.9 & 0.2 \\
\hline DK & 198.6 & 85.6 & 214.5 & 85.2 & 229.3 & 84.1 & 234.6 & 84.5 & 234.1 & 82.8 & 4.2 & -0.8 \\
\hline DE & 49.7 & 54.3 & 49.7 & 55.4 & 48.6 & 55.9 & 47.1 & 56.0 & 46.8 & 56.0 & -1.5 & 0.8 \\
\hline $\mathrm{EE}$ & 44.6 & 82.4 & 60.6 & 82.4 & 66.4 & 81.1 & 68.1 & 80.6 & 75.2 & 81.7 & 14.0 & -0.2 \\
\hline $\mathrm{IE}$ & 116.7 & 82.3 & 128.1 & 83.4 & 133.3 & 83.6 & 117.8 & 83.1 & 120.6 & 85.0 & 0.8 & 0.8 \\
\hline$E L$ & 32.4 & 65.7 & 38.4 & 66.4 & 41.5 & 66.5 & 45.3 & 66.2 & 45.3 & 67.2 & 8.7 & 0.6 \\
\hline ES & 75.8 & 72.5 & 86.5 & 73.5 & 92.4 & 74.2 & 91.6 & 74.4 & 90.4 & 74.8 & 4.5 & 0.8 \\
\hline FR & 42.9 & 69.8 & 47.1 & 72.0 & 50.5 & 73.4 & 52.5 & 74.6 & 53.8 & 75.1 & 5.8 & 1.9 \\
\hline IT & 21.9 & 51.7 & 23.8 & 52.4 & 25.1 & 52.2 & 24.2 & 50.7 & 25.4 & 50.8 & 3.8 & -0.4 \\
\hline LV & 30.6 & 64.0 & 46.6 & 67.9 & 54.9 & 70.7 & 47.8 & 69.7 & 47.9 & 69.9 & 11.9 & 2.2 \\
\hline LT & 13.8 & 69.0 & 19.3 & 65.2 & 28.0 & 66.8 & 29.7 & 69.4 & 34.2 & 72.0 & 25.5 & 1.1 \\
\hline $\mathrm{HU}$ & 16.9 & 58.9 & 20.1 & 59.3 & 21.1 & 52.4 & 24.4 & 47.7 & 27.5 & 52.4 & 12.9 & -2.9 \\
\hline $\mathrm{NL}$ & 159.7 & 90.3 & 169.1 & 89.9 & 171.5 & 91.1 & 178.1 & 91.7 & 184.1 & 92.1 & 3.6 & 0.5 \\
\hline AT & 33.7 & 49.3 & 36.1 & 53.5 & 37.0 & 54.3 & 38.8 & 56.3 & 39.1 & 57.2 & 3.8 & 3.8 \\
\hline
\end{tabular}


Table 2. (continued)

\begin{tabular}{|c|c|c|c|c|c|c|c|c|c|c|c|c|}
\hline \multirow[t]{2}{*}{ Country $^{b}$} & \multicolumn{2}{|c|}{2005} & \multicolumn{2}{|c|}{2006} & \multicolumn{2}{|c|}{2007} & \multicolumn{2}{|c|}{2008} & \multicolumn{2}{|c|}{2009} & \multicolumn{2}{|c|}{ average annual change } \\
\hline & । & $\|$ & I & $\|$ & 1 & $\|$ & 1 & $\|$ & । & $\|$ & I & $\|$ \\
\hline $\mathrm{PL}$ & 7.9 & 38.5 & 11.2 & 42.9 & 16.3 & 48.4 & 20.0 & 44.1 & 26.7 & 54.8 & 35.6 & 9.2 \\
\hline PT & 75.0 & 79.4 & 83.5 & 79.7 & 89.3 & 79.0 & 88.5 & 78.8 & 93.0 & 79.6 & 5.5 & 0.1 \\
\hline $\mathrm{RO}$ & 2.9 & 24.8 & 4.0 & 20.4 & 5.3 & 20.0 & 6.1 & 21.0 & 7.8 & 24.1 & 28.1 & -0.6 \\
\hline $\mathrm{SI}$ & 7.3 & 32.2 & 9.9 & 36.3 & 12.5 & 39.2 & 14.6 & 43.5 & 17.0 & 46.6 & 23.5 & 9.7 \\
\hline SK & 13.4 & 65.7 & 17.3 & 65.8 & 18.7 & 67.0 & 22.1 & 67.6 & 24.1 & 67.9 & 15.8 & 0.8 \\
\hline $\mathrm{Fl}$ & 55.0 & 70.2 & 60.1 & 71.0 & 63.6 & 71.8 & 65.4 & 72.4 & 67.7 & 73.0 & 5.3 & 1.0 \\
\hline SE & 72.3 & 62.8 & 80.7 & 65.7 & 80.3 & 63.0 & 75.6 & 57.8 & 96.0 & 69.0 & 7.3 & 2.4 \\
\hline UK & 118.0 & 79.5 & 129.6 & 82.2 & 126.8 & 76.2 & 112.2 & 68.0 & 135.3 & 82.0 & 3.5 & 0.8 \\
\hline EU & 52.6 & 65.8 & 56.5 & 66.7 & 61.8 & 69.3 & 66.8 & 71.2 & 67.9 & 70.1 & 6.6 & 1.6 \\
\hline
\end{tabular}

aThe data shown in the table covers: I - the relation of mortgages to households' disposable incomes, II - the share of mortgages in all debts.

bBE-Belgium, BG-Bulgaria, CZ-Czech Republic, DK-Denmark, DE-Germany, EE-Estonia, IE-Ireland, EL-Greece, ES-Spain, FRFrance, IT-Italy, LV-Latvia, LT-Lithuania, HU-Hungary, NL-the Netherlands, AT-Austria, PL-Poland, PT-Portugal, RO-Romania, SI-Slovenia, SK-Slovakia, FI-Finland, SE-Sweden, UK- Great Britain, EU-the European Union

In 2009, the mortgages and flat loans in Bulgaria, Poland and Slovenia constituted about a half of all debts while they only amounted to $1 \frac{1}{4}$ in Romania. Moreover, although such little meaning of mortgages in Romania, there was a slight declining tendency in their share in the structure of debts.

The increasing meaning of mortgages is also indicated by the changes in the general structure of households' indebtedness in the European Union (Table 2). The highest dynamics of changes was observed in Bulgaria where the annual average share of mortgages in all debts increased by nearly $12 \%$. Only five countries had a reverse trend, but in four of these, the changes were relatively insignificant - the share of mortgages in the structure of indebtedness decreased annually on average by $0.2-0.8 \%$. A relatively stronger declining tendency was observed in Hungary where the share of mortgages in all households' debts decreased by nearly $3 \%$.

Consumption credits constitute another important element of households' indebtedness. The level of households' indebtedness due to these credits in proportion to disposable incomes, their share in the general structure of debts and the dynamics of changes of both their measurements are presented in Table 3

The meaning of consumption credits has been on the decrease in most EU countries in recent years. It also declined in the analyzed period. Between 2005 and 2009, the share of consumption indebtedness in the general structure of indebtedness decreased by about 5\% annually, except for Estonia, Italy, Portugal and Hungary where tendencies of growth were observed. The data presented also shows that only two countries (Romania and Bulgaria), consumption credits constituted the main parts of indebtedness and in relation to incomes.

As regards Romania in 2009, repayments of consumption credits constituted almost $75 \%$ of disposable incomes while the proportion exceeded 50\% in Bulgaria. Consumption credits also constituted a significant burden for the disposable incomes of Hungarian households.

Despite the decreasing meaning of consumption credits in the structure of households' indebtedness, there was an increase in the proportion of the volume of consumption credits related to disposable incomes in the majority of EU countries. The highest dynamics could be observed 
in Hungary and Romania where, in the analyzed period, repayments of consumption debts constituted a burden of $50 \%$ of disposable incomes on average.

In 2009 in four countries: Bulgaria, Hungary, Romania and Great Britain, as much as $25 \%$ of all households' disposable incomes were obliged to repay consumption credits. However, in spite of such high level of indebtedness, except for Great Britain, the countries were characterized by a very high dynamics of growth regarding this ratio. The countries with the lowest amount of consumption credits included Slovakia and Lithuania. These countries had their household indebted due to consumption credits in only $5 \%$ (2009.)

Table 3. Households' indebtedness due to consumption credit in EU countries between 2005 and $2009(\%)^{\mathrm{a}}$

\begin{tabular}{|c|c|c|c|c|c|c|c|c|c|c|c|c|}
\hline \multirow[t]{2}{*}{ Country ${ }^{b}$} & \multicolumn{2}{|c|}{2005} & \multicolumn{2}{|c|}{2006} & \multicolumn{2}{|c|}{2007} & \multicolumn{2}{|c|}{2008} & \multicolumn{2}{|c|}{2009} & \multicolumn{2}{|c|}{ average annual change } \\
\hline & I & $\|$ & I & $\|$ & I & $\|$ & I & $\|$ & 1 & $\|$ & I & $\|$ \\
\hline $\mathrm{BE}$ & 8.2 & 11.1 & 8.5 & 11.0 & 9.0 & 11.1 & 9.3 & 11.1 & 9.1 & 10.5 & 2.6 & -1.3 \\
\hline$B G$ & 17.7 & 61.7 & 18.1 & 53.1 & 23.9 & 51.8 & 26.0 & 51.2 & 26.5 & 51.2 & 10.6 & -4.6 \\
\hline$C Z$ & 5.7 & 21.5 & 6.5 & 20.4 & 7.4 & 19.0 & 8.4 & 19.3 & 9.0 & 19.0 & 12.1 & -3.1 \\
\hline DK & 14.0 & 6.0 & 15.3 & 6.1 & 17.9 & 6.6 & 17.6 & 6.3 & 15.1 & 5.3 & 1.9 & -3.0 \\
\hline DE & 14.9 & 16.3 & 14.3 & 15.9 & 13.7 & 15.8 & 13.4 & 15.9 & 13.5 & 16.1 & -2.4 & -0.2 \\
\hline $\mathrm{EE}$ & 4.8 & 8.9 & 7.5 & 10.2 & 9.3 & 11.4 & 9.3 & 11.0 & 9.3 & 10.1 & 18.0 & 3.3 \\
\hline IE & 20.4 & 14.4 & 19.5 & 12.7 & 19.7 & 12.4 & 18.6 & 13.1 & 18.6 & 13.1 & -2.3 & -2.3 \\
\hline EL & 15.6 & 31.6 & 17.9 & 31.0 & 19.2 & 30.8 & 21.3 & 31.1 & 20.3 & 30.1 & 6.8 & -1.2 \\
\hline ES & 13.0 & 12.4 & 14.5 & 12.3 & 15.3 & 12.3 & 14.3 & 11.6 & 12.9 & 10.7 & -0.2 & -3.7 \\
\hline FR & 12.3 & 20.0 & 12.3 & 18.8 & 12.3 & 17.9 & 11.9 & 16.9 & 11.7 & 16.3 & -1.2 & -4.9 \\
\hline $\mathrm{IT}$ & 7.3 & 17.2 & 8.3 & 18.3 & 9.2 & 19.1 & 9.7 & 20.3 & 10.2 & 20.4 & 8.7 & 4.3 \\
\hline LV & 6.4 & 13.4 & 8.5 & 12.4 & 8.4 & 10.8 & 7.6 & 11.1 & 7.1 & 10.4 & 2.6 & -6.2 \\
\hline LT & 3.3 & 16.5 & 4.8 & 16.2 & 6.1 & 14.6 & 6.2 & 14.5 & 5.8 & 12.2 & 15.1 & -7.3 \\
\hline $\mathrm{HU}$ & 9.1 & 31.7 & 12.3 & 36.3 & 16.6 & 41.2 & 22.7 & 44.3 & 23.4 & 44.6 & 26.6 & 8.9 \\
\hline $\mathrm{NL}$ & 9.3 & 5.3 & 9.3 & 4.9 & 8.6 & 4.6 & 8.6 & 4.4 & 8.4 & 4.2 & -2.5 & -5.4 \\
\hline AT & 17.3 & 25.3 & 14.9 & 22.1 & 14.2 & 20.8 & 13.3 & 19.3 & 12.6 & 18.4 & -7.6 & -7.6 \\
\hline$P L$ & 9.6 & 46.8 & 11.0 & 42.1 & 13.6 & 40.4 & 16.8 & 37.0 & 18.2 & 37.4 & 17.3 & -5.5 \\
\hline PT & 8.9 & 9.4 & 10.4 & 9.9 & 12.2 & 10.8 & 13.1 & 11.7 & 13.3 & 11.4 & 10.6 & 4.8 \\
\hline $\mathrm{RO}$ & 8.6 & 73.5 & 15.2 & 77.6 & 20.4 & 77.0 & 21.6 & 74.2 & 23.4 & 72.4 & 28.4 & -0.4 \\
\hline SI & 10.5 & 46.3 & 11.6 & 42.5 & 12.8 & 40.1 & 12.4 & 36.9 & 12.6 & 34.5 & 4.7 & -7.1 \\
\hline SK & 2.8 & 13.7 & 4.0 & 15.2 & 3.8 & 13.6 & 4.4 & 13.5 & 4.9 & 13.8 & 15.0 & 0.1 \\
\hline $\mathrm{FI}$ & 10.7 & 13.7 & 11.3 & 13.3 & 11.5 & 13.0 & 11.7 & 13.0 & 11.7 & 12.6 & 2.3 & -2.0 \\
\hline SE & 7.7 & 6.7 & 8.4 & 6.8 & 8.7 & 6.8 & 8.9 & 6.8 & 9.1 & 6.5 & 4.3 & -0.5 \\
\hline UK & 25.8 & 17.4 & 25.2 & 16.0 & 25.4 & 15.3 & 25.5 & 15.4 & 24.8 & 15.0 & -1.0 & -3.6 \\
\hline EU & 14.5 & 18.1 & 14.6 & 17.2 & 14.9 & 16.7 & 14.8 & 15.8 & 14.4 & 14.9 & -0.2 & -4.8 \\
\hline
\end{tabular}

'The data shown in the table covers: I - the relation of consumption credits to households' disposable incomes, II - the share of consumption credits in all debts.

${ }^{b}$ BE-Belgium, BG-Bulgaria, CZ-Czech Republic, DK-Denmark, DE-Germany, EE-Estonia, IE-Ireland, EL-Greece, ES-Spain, FRFrance, IT-Italy, LV-Latvia, LT-Lithuania, HU-Hungary, NL-the Netherlands, AT-Austria, PL-Poland, PT-Portugal, RO-Romania, SI-Slovenia, SK-Slovakia, FI-Finland, SE-Sweden, UK- Great Britain, EU-the European Union 
The last analyzed type of households' indebtedness is the indebtedness which does not belong to any of the categories of mortgages or consumption credits. Its level and dynamics are presented in Table 4. The volume of indebtedness due to other credits in pro- portion to households' disposable incomes increased between 2005 and 2009. As regards the whole EU, the indebtedness due to other credits reached on average $3 \%$ more each year.

Table 4. Households' indebtedness due to other credits in EU countries between 2005 and 2009. (\%)

\begin{tabular}{|c|c|c|c|c|c|c|c|c|c|c|c|c|}
\hline \multirow[t]{2}{*}{ Country $^{b}$} & \multicolumn{2}{|c|}{2005} & \multicolumn{2}{|c|}{2006} & \multicolumn{2}{|c|}{2007} & \multicolumn{2}{|c|}{2008} & \multicolumn{2}{|c|}{2009} & \multicolumn{2}{|c|}{ average annual change } \\
\hline & I & $\|$ & 1 & $\|$ & । & $\|$ & I & $\|$ & 1 & $\|$ & 1 & $\|$ \\
\hline $\mathrm{BE}$ & 11.4 & 15.4 & 11.2 & 14.4 & 10.6 & 13.1 & 10.7 & 12.8 & 10.6 & 12.3 & -1.8 & -5.6 \\
\hline$B G$ & 2.9 & 10.1 & 3.1 & 9.1 & 3.4 & 7.4 & 3.1 & 6.1 & 2.6 & 5.0 & -2.7 & -16.0 \\
\hline$C Z$ & 2.4 & 9.1 & 2.6 & 8.2 & 2.8 & 7.2 & 6.7 & 15.4 & 5.2 & 11.0 & 21.3 & 4.9 \\
\hline DK & 19.4 & 8.4 & 22.0 & 8.7 & 25.5 & 9.4 & 25.3 & 9.1 & 33.6 & 11.9 & 14.7 & 9.2 \\
\hline DE & 27.0 & 29.5 & 25.7 & 28.7 & 24.6 & 28.3 & 23.6 & 28.1 & 23.3 & 27.9 & -3.6 & -1.4 \\
\hline $\mathrm{EE}$ & 4.7 & 8.7 & 5.4 & 7.3 & 6.2 & 7.6 & 7.1 & 8.4 & 7.5 & 8.2 & 12.4 & -1.6 \\
\hline IE & 4.7 & 3.3 & 6.0 & 3.9 & 6.5 & 4.1 & 5.4 & 3.8 & 2.6 & 1.8 & -13.8 & -13.8 \\
\hline $\mathrm{EL}$ & 1.3 & 2.6 & 1.5 & 2.6 & 1.7 & 2.7 & 1.8 & 2.6 & 1.8 & 2.7 & 8.5 & 0.3 \\
\hline ES & 15.7 & 15.0 & 16.7 & 14.2 & 16.9 & 13.6 & 17.2 & 14.0 & 17.5 & 14.5 & 2.8 & -0.9 \\
\hline $\mathrm{FR}$ & 6.3 & 10.2 & 6.0 & 9.2 & 6.0 & 8.7 & 6.0 & 8.5 & 6.1 & 8.5 & -0.8 & -4.5 \\
\hline IT & 13.2 & 31.1 & 13.3 & 29.3 & 13.8 & 28.7 & 13.8 & 28.9 & 14.4 & 28.8 & 2.2 & -1.9 \\
\hline LV & 10.8 & 22.6 & 13.5 & 19.7 & 14.4 & 18.5 & 13.2 & 19.2 & 13.5 & 19.7 & 5.7 & -3.4 \\
\hline LT & 2.9 & 14.5 & 5.5 & 18.6 & 7.8 & 18.6 & 6.9 & 16.1 & 7.5 & 15.8 & 26.8 & 2.2 \\
\hline $\mathrm{HU}$ & 2.7 & 9.4 & 1.5 & 4.4 & 2.6 & 6.5 & 4.1 & 8.0 & 1.6 & 3.0 & -12.3 & -24.6 \\
\hline $\mathrm{NL}$ & 7.9 & 4.5 & 9.6 & 5.1 & 8.2 & 4.4 & 7.5 & 3.9 & 7.3 & 3.7 & -2.0 & -4.9 \\
\hline AT & 17.3 & 25.3 & 16.5 & 24.4 & 17.0 & 24.9 & 16.8 & 24.4 & 16.6 & 24.3 & -1.0 & -1.0 \\
\hline$P L$ & 3.0 & 14.6 & 3.9 & 14.9 & 3.8 & 11.3 & 8.6 & 18.9 & 3.8 & 7.8 & 6.1 & -14.5 \\
\hline PT & 10.5 & 11.1 & 10.9 & 10.4 & 11.5 & 10.2 & 10.7 & 9.5 & 10.5 & 9.0 & 0.0 & -5.2 \\
\hline $\mathrm{RO}$ & 0.2 & 1.7 & 0.4 & 2.0 & 0.8 & 3.0 & 1.4 & 4.8 & 1.1 & 3.4 & 53.1 & 18.8 \\
\hline SI & 4.9 & 21.6 & 5.8 & 21.2 & 6.6 & 20.7 & 6.6 & 19.6 & 6.9 & 18.9 & 8.9 & -3.3 \\
\hline SK & 4.2 & 20.6 & 5.0 & 19.0 & 5.4 & 19.4 & 6.2 & 19.0 & 6.5 & 18.3 & 11.5 & -2.9 \\
\hline $\mathrm{Fl}$ & 12.6 & 16.1 & 13.3 & 15.7 & 13.5 & 15.2 & 13.2 & 14.6 & 13.3 & 14.3 & 1.4 & -2.8 \\
\hline SE & 35.2 & 30.6 & 33.8 & 27.5 & 38.4 & 30.1 & 46.3 & 35.4 & 34.0 & 24.4 & -0.9 & -5.4 \\
\hline UK & 4.6 & 3.1 & 2.8 & 1.8 & 14.2 & 8.5 & 27.4 & 16.6 & 4.8 & 2.9 & 1.1 & -1.6 \\
\hline EU & 12.9 & 16.1 & 13.6 & 16.1 & 12.5 & 14.0 & 12.2 & 13.0 & 14.6 & 15.1 & 3.1 & -1.7 \\
\hline
\end{tabular}

aThe data shown in the table covers: I - the relation of other credits to households' disposable incomes, II - the share of other credits in all debts.

bBE-Belgium, BG-Bulgaria, CZ-Czech Republic, DK-Denmark, DE-Germany, EE-Estonia, IE- Ireland, EL-Greece, ES-Spain, FRFrance, IT-Italy, LV-Latvia, LT-Lithuania, HU-Hungary, NL-the Netherlands, AT-Austria, PL-Poland, PT-Portugal, RO-Romania, SI-Slovenia, SK-Slovakia, FI-Finland, SE-Sweden, UK- Great Britain, EU-the European Union 
The most heavily indebted households included Danish and Swedish households which had the proportion of other credits to disposable incomes of about $33,3 \%$. As regards the general structure of indebtedness, other credits had relatively little meaning. Moreover, their share was on the decrease year after year. Only four countries, i.e. Sweden, Austria, Germany and Italy, they constituted relatively important elements of indebtedness, amounting to about $25 \%$ of the general volume of indebtedness.

To sum up, a tendency can be observed among households in the European Union to increase their indebtedness level, measured as the proportions of credit indebtedness to disposable incomes. Flat loans and mortgages constitute the most important element here, also characterized by the highest dynamics. Moreover, the share of mortgages and flat loans in the general structure of indebtedness also increased in the analyzed period as opposed to the meaning of consumption and other credits.

\section{Households' problems with regular repayment of obligations}

The data presented above quite distinctively draws the scale of the problem of households' indebtedness, measured as the proportion of debt to disposable incomes. It is difficult, however, to describe the influence of increasing indebtedness on the economic and financial situation in households, which is, to a large degree, influenced by payments connected with debt service.

For it is the impossibility to repay on time and not the level of indebtedness that mainly contributes to the deterioration of financial condition which can result in insolvency.

The range of the problem is reflected by the data shown in Table 5. Its analysis implies that the Bulgarians have the greatest problems with debt repayment as every third household declared difficulties in repaying at least one of the following obligations: mortgages, rent credits, other credits and municipal charges. At the same time, as many as $25 \%$ of households in Greece and Romania acknowledged that they had problems repaying at least one liability.

The most systematic repayments were observed in the Netherlands, Czech Republic and Denmark where only $4 \%$ of households confessed to repayment problems.
The typology of households in EU countries according to the level and structure of indebtedness and the range of repayment problems

Basing on the data from 2008 included in tables 1-5, particular EU countries were divided into 7 groups characterized by different level and structure of households' indebtedness as well as repayment problems. The outcomes of the classification obtained by means of data clustering ${ }^{3}$ are presented in Table 6 .

The first group includes countries such as Ireland, Spain, Portugal, Sweden and Great Britain. It is a group of countries whose households are heavily indebted and in which credit indebtedness exceeded households' incomes. As regards indebtedness structure, mortgages constituted the dominating part, i.e. about $75 \%$ of the value of all credits. The households in question had, however, relatively fewer repayment problems, and only $7 \%$ declared them.

Greece is classified in group two as its only element. It was characterized by much lower a rate of households' credit indebtedness in proportion to disposable incomes. Credit indebtedness in Greece amounted to nearly 70\% of households' disposable incomes. However, considerable repayment problems were observed in this country, as every fourth household declared serious problems repaying at least one obligation. It might be caused by consumption credit indebtedness, which amounted to almost $1 / 3$ of the total value of all credits.

The next typological group consists of Belgium, Germany, Estonia, Latvia, Austria and Finland. It is a group of countries in which households are characterized by a medium level of indebtedness whose proportion to disposable incomes was lower than the average for the EU.

The value of the indebtedness ratio in this group amounted to $80 \%$. It is worth stressing that the declared problems repaying liabilities concerned a lower number of households than the average number in the EU. However, as regards households' indebtedness structure in these countries, the debts were constituted mainly by mortgages (70\%), commonly believed to be served best.

Denmark and the Netherlands constitute a separate group. It is the most heavily indebted group in which the credit where households' indebtedness exceeds their disposable incomes more than twice. Such high level of indebtedness was mainly the consequence of mortgages and flat loans, which amounted to almost 
Table 5. Percentage of households declaring arrears in repaying at least one liability in EU countries (data from 2008)

\begin{tabular}{cccc}
\hline Country & $\begin{array}{c}\text { \% of households with } \\
\text { arrears (at least one liability) }\end{array}$ & Country & $\begin{array}{c}\text { \% of households with } \\
\text { arrears (at least one liability) }\end{array}$ \\
\hline Belgium & 33.4 & Hungary & 16.0 \\
Bulgaria & 3.9 & The Netherlands & 6.5 \\
Czech Republic & 3.9 & Poland & 11.3 \\
Denmark & 5.7 & Portugal & 5.0 \\
Germany & 7.6 & Romania & 26.6 \\
Estonia & 11.6 & Slovenia & 16.5 \\
Ireland & 24.5 & Slovakia & 5.0 \\
Greece & 6.8 & Finland & 9.4 \\
Spain & - & Sweden & 5.4 \\
France & 14.9 & Great Britain & \\
Italy & 13.3 & UE & 7.1 \\
Latvia & 7.5 & & 10.9 \\
Lithuania & & & 5.4 \\
\hline
\end{tabular}

Note. Each household had arrears repaying at least one of the following liabilities: mortgage repayment, rent, credit repayment (other than mortgage), municipal charges.

Table 6. Classification of EU countries according to the level and structure of indebtedness and repayment problems - average percentages for particular indebtedness groups (data from 2008)

\begin{tabular}{|c|c|c|c|c|c|c|c|c|c|}
\hline \multicolumn{2}{|c|}{ Group number } & 1 & 2 & 3 & 4 & 5 & 6 & 7 & UE \\
\hline \multicolumn{2}{|c|}{ Countries belonging to the group } & $\begin{array}{l}\text { IE, ES, } \\
\text { PT, SE, } \\
\text { UK }\end{array}$ & EL & $\begin{array}{l}B E, D E \\
E E, L V \\
A T, F I\end{array}$ & $\mathrm{DK}, \mathrm{NL}$ & IT, SI, PL & $\begin{array}{l}C Z, L T, \\
S K\end{array}$ & $\begin{array}{l}\mathrm{BG}, \mathrm{RO}, \\
\mathrm{HU}\end{array}$ & \\
\hline \multirow{4}{*}{$\begin{array}{l}\text { Credit } \\
\text { indebtedness } \\
\text { share in } \\
\text { disposable } \\
\text { incomes (\%) }\end{array}$} & Credit indebtedness total & 134.6 & 68.4 & 80.0 & 235.9 & 42.2 & 39.6 & 43.7 & 93.8 \\
\hline & Mortgages & 97.1 & 45.3 & 55.1 & 206.4 & 19.6 & 26.8 & 17.4 & 66.8 \\
\hline & Consumption credit & 16.1 & 21.3 & 10.8 & 13.1 & 13.0 & 6.3 & 23.4 & 14.8 \\
\hline & Other credits & 21.4 & 1.8 & 14.1 & 16.4 & 9.7 & 19.8 & 2.9 & 12.2 \\
\hline \multirow{3}{*}{$\begin{array}{l}\text { Credit } \\
\text { indebtedness } \\
\text { structure(\%) }\end{array}$} & Mortgages & 72.4 & 66.2 & 68.5 & 88.1 & 46.1 & 67.4 & 37.1 & 71.2 \\
\hline & Consumption credit & 11.7 & 31.1 & 13.6 & 5.4 & 31.4 & 15.7 & 56.6 & 15.8 \\
\hline & Other credits & 15.9 & 2.6 & 17.9 & 6.5 & 22.5 & 16.8 & 6.3 & 13.0 \\
\hline \multicolumn{2}{|c|}{$\begin{array}{l}\text { Households declaring arrears in in } \\
\text { repaying at least one liability (\%) }\end{array}$} & 7.2 & 24.5 & 8.2 & 3.7 & 14.2 & 5.5 & 25.4 & 11.0 \\
\hline
\end{tabular}

aBE-Belgium, BG-Bulgaria, CZ-Czech Republic, DK-Denmark, DE-Germany, EE-Estonia, IE-Ireland, EL-Greece, ES-Spain, IT-Italy, LV-Latvia, LT-Lithuania, HU-Hungary, NL-the Netherlands, AT-Austria, PL-Poland, PT-Portugal, RO-Romania, SI-Slovenia, SKSlovakia, Fl-Finland, SE-Sweden, UK- Great Britain, UE-the European Union 
$90 \%$ of all credits. In spite of such considerable burden for disposable incomes, households in these countries showed the fewest problems with regular repayment of all due liabilities. Only nearly $4 \%$ of households declared arrears in repaying at least one liability.

Group five included Italy, Slovenia and Poland, i.e. countries where households were indebted in a really low proportion, but they encountered problems repaying liabilities more often than on average. Every seventh household in this group declared problems with timely repayment of liabilities. However, there was a considerable share of consumption credits which amounted to as much as $33,3 \%$ of all credits. Moreover, the analyzed group of countries was characterized by the largest proportion of credits due to other than accommodation and consumption reasons.

Group six included Czech Republic, Lithuania and Slovakia. It is the least indebted group of countries whose debt constitutes a burden for households' disposable incomes in only about $40 \%$ and there were no significant repayment problems. Only slightly more than $5 \%$ of households in this group declared problems with timely repayment of liabilities, which could result from the dominant share of mortgages which amounted to $66,6 \%$ of all credits.

The final group distinguished in the taxonomy included Bulgaria, Romania and Hungary - countries with very low rates of households' indebtedness. Credits in these countries amounted for about a half of their disposable incomes. The households in these countries, in spite of such low level of indebtedness, reported the greatest repayment problems. On average, every fourth household declared arrears in repaying at least one liability. However, it needs to be stressed that the structure of credits was dominated by consumption credits which accounted for more than $50 \%$ of all debts.

\section{Quantity analysis of the influence of selected variables on the frequency of repayment problems in EU countries}

In order to describe the strength and direction of the selected variables on the frequency of repayment problems, analysis of correlation and the method of stepwise regressions were used. The problem was analyzed in two versions and only based on data from 2008 for which it was possible because of the availability of data. The following variables appear in the first option:
$Y_{1}$ - frequency of reporting debt service difficulties measured as \% of households reporting this kind of difficulties,

$X_{1}$ - proportion of general credit indebtedness to disposable income $(\%)$,

$X_{2}$ - proportion of mortgages to disposable income (\%),

$X_{3}$ - proportion of consumption credit to disposable income (\%),

$X_{4}$ - proportion of other credits to disposable income (\%).

The other version analyzed quantity relationships between reporting debt service problems depending on the share of particular credits in total credit indebtedness:

$Y_{2}$ - frequency of reporting debt service problems measured as \% of households reporting this kind of problems,

$X_{5}$ - share of mortgages in total indebtedness (\%),

$X_{6}$ - share of consumption credits in total indebtedness (\%),

$X_{7}$ - share of consumption due to other credit in total indebtedness (\%).

Table 7 presents the matrix of correlation between the analyzed variables. The analysis of correlation ratios shows a high and, in a vast majority of cases, significant relationship between the ratios of indebtedness structure and the frequency of problems with its service, measured as the percentage of households reporting arrears in repaying at least one liability.

In light of the above data, debt service problems were to the largest degree connected with financing households through consumption credits $\left(X_{3}, X_{6}\right)$. In this case they amounted to $R=0.611$ and $R=0.824$ respectively, which confirms the earlier observations that the more the share of these credit is in proportion to disposable incomes or total indebtedness, the greater the percentage of arrears.

The variables describing mortgage indebtedness $\left(X_{2}, X_{5}\right)$ show a negative, but also very strong correlation. They amount to $R=-0.611$ and $R=-0.824$, which means that the greater the proportion of mortgages in disposable incomes or in all credits is, the less frequently repayment problems are reported. The values of correlation ratios for the variables $X_{1}$ and $X_{4}$ show a similar character of the relationship. It is possible to interpret is as follows: an increase in the general indebtedness in proportion to disposable incomes and using the so-called other credits did not imply an ex- 
pansion of debt service problems, but on the contrary, a lower frequency of reported arrears $(\mathrm{R}=-0.444, \mathrm{R}=$ $-0.476)$.

The conclusions, drawn on the basis of correlation analysis, also confirm the estimated parameters of linear regression function:

$Y 1=-0.0611 X_{2}+1,0248 X_{3}$

$\left(p_{2}=0.0037\right)\left(p_{3}=0.0000\right)$

$\left(\beta_{2}=-0.379\right)\left(\beta_{3}=1.158\right)$

$F(2.21)=64.458 ; R^{2}=84.66 \%$

Interpreting the parameters of the first regression model $\left(Y_{1}\right)$ shows unequivocally that the higher the proportion of indebtedness due to consumption credits to disposable income $\left(X_{3}\right)$ is and, at the same time, the lower it is if it is due to mortgages $\left(X_{2}\right)$, the greater the range of problems with arrears is. Both variables describe, to a large degree, the variability of credit repayment problems $(84.66 \%)$, however, it can be noticed that the negative influence of consumption debts is here, according to the $\beta$ measurement, clearly stronger than the favorable influence of mortgages.

Analyzing the parameters of the regression function, $Y_{2}$, lets one arrive at coherent conclusions. It reflects quantity relationships connected with the structure of total indebtedness. They show unequivocally that the increase in the share of mortgages in total indebtedness $\left(X_{5}\right)$ significantly reduced the percentage of households reporting debt service problems, while the increase of the share of consumption credits in total indebtedness $\left(X_{6}\right)$ resulted in considerable expansion of repayment problems.

Table 7. Correlation matrix $(R)$ - Pearson coefficient between the analyzed variables

\begin{tabular}{|c|c|c|c|c|c|c|c|c|}
\hline & $x_{1}$ & $x_{2}$ & $x_{3}$ & $X_{4}$ & $X_{5}$ & $x_{6}$ & $x_{7}$ & $Y_{1,2}$ \\
\hline$x_{i}$ & 1.000 & 0.984 & 0.132 & 0.504 & 0.648 & -0.545 & -0.186 & -0.444 \\
\hline$x_{2}$ & & 1.000 & 0.053 & 0.376 & 0.725 & -0.573 & -0.278 & -0.466 \\
\hline$x_{3}$ & & & 1.000 & -0.111 & -0.372 & 0.596 & -0.443 & 0.611 \\
\hline$x_{4}$ & & & & 1.000 & 0.143 & -0.487 & 0.669 & -0.476 \\
\hline$x_{5}$ & & & & & 1.000 & -0.865 & -0.237 & -0.650 \\
\hline$x_{6}$ & & & & & & 1.000 & -0.281 & 0.824 \\
\hline$x_{7}$ & & & & & & & 1,000 & $-0,354$ \\
\hline$Y_{1,2}$ & & & & & & & \multicolumn{2}{|c|}{1,000} \\
\hline
\end{tabular}

Note. Statistically significant correlations have been bolded $(p<0,05)$

$Y_{2}=30.740-0.310 X_{5}$

$\left(p_{5}=0.0008\right)\left(\beta_{5}=-0.650\right)$

$F(1.21)=15.395 ; R^{2}=39.55 \%$

$Y_{2}=2.644+0.388 X_{6}$

$\left(p_{6}=0.0000\right)\left(\beta_{6}=0.824\right)$

$F(1.21)=44.689 ; R^{2}=68.03 \%$

It also needs to be stressed that the degree to which the variability of the number of households reporting debt service problems is considerably higher in the model taking into account consumption credits ( $22=68.03 \%)$. It means that this particular kind of credits is, for EU households, the main source of financial problems.

\section{Summary}

Households' over-indebtedness is presently becoming a very important social and economic problem for both highly developed countries and emerging markets. However, the problem has a dual nature. As regards developed countries, in spite of a relatively good rate of repayment, the increasing level of households' 
indebtedness is gradually becoming a problem. On the other hand, in the remaining countries, the high dynamics of the increase, in spite of the still low level of households' indebtedness - is starting to overcome the pace of income rise. Although there are a number of reasons for it, in times of crisis, such phenomena as excessive consumption, lack of knowledge or limited financial awareness constitute the factors which particularly strongly affect households' financial condition, resulting, in a number of cases, in arrears and even insolvency. The conducted research also seems to emphasize the particular role of financial institutions in preventing those negative phenomena from happening. Easy access to credits and, particularly, consumption credits, has already led to serious problems in households, but also serious problems of the crediting financial institutions, which, as a consequence, resulted in a number of negative tendencies in the macro scale. One may imply that the world economic and financial crisis will enforce significant changes in this respect. Households are an integral element of each social and economic system, which means that the debt service problems that they encounter will negatively influence the whole economy in the long run.

\section{References}

Barba, A., Pivetti, M. (2009). Rising household debt: Its causes and macroeconomic implications-a longperiod analysis, Cambridge Journal of Economics, $33,113-137$

Betti, G., Dourmashkin, N., Rossi, M., Ping Yin, Y. (2007). Consumer over-indebtedness in the EU: measurement and characteristics, Journal of Economic Studies, 34(2), 136-156.

Bloxham, P., Kent, Ch. (2009). Household indebtedness, The Australian Economic Review, 42(3), 327-39.

Brown, S., Taylor K. (2008). Household debt and financial assets: evidence from Germany, Great Britain and the USA, Journal of the Royal Statistical Society: Series A, 171(3), 615-643.

BIS. Department for Business Innovation and Skills. (2010). Over-indebtedness in Britain: second follow-up report.

Bywalec, Cz. (2009). Ekonomika i finanse gospodarstw domowych. [Economics and Financials of households]. Warsaw: PWN.
Dynan, K. (2009). Changing household financial opportunities and economic security, Journal of Economic Perspectives, 23(4), 49-68.

European Commission (Directorate-General for Employment, Social Affairs and Equal Opportunities). (2008). Towards a common operational European definition of overindebtedness.

European Credit Research Institute and Personal Finance Research Centre. (2008). Consumer financial vulnerability: technical report. Brussels: European Credit Research Institute.

Fondeville, N., Ozdemir, E., Ward, T. (2010). Research note 4/2010. Over-indebtness. New evidence from EU-SILC special module. Brussels: European Commission, Directorate- General for Employment, Social Affairs and Equal Opportunities.

Gumy, J. (2007). Explaining Overindebtedness in the European Union. Paper prepared for the BHPS 2007 Conference Colchester, 5th-7th July 2007

Joyce, P. (2003) An End Based on Means? Dublin: Free Legal Advice Centres

Kempson, E. (2002). Over-indebtedness in Britain. A report to the Deparment of Trade and Industry. Bristol, UK: Personal Finance Research Centre, School of Geographical Sciences, University of Bristol.

Law Reform Commission. (2009). Consultation Paper on personal debt management and debtenforcement. Ballsbridge: Law Reform Commision.

Lea, S. E. G., Webley, P., Walker, C. M. (1995). Psychological factors in consumer debt: Money management, economic socialization, and credit use. Journal of Economic Psychology, 16(4), 681-701.

Lilico, A. (2010). Household Indebtness in the EU. Brussels: European Parliament.

Niemi-Kiesiläinen, J., Henrikson, A. (2005). Report on legal solutions to debt problems in credit societies. Strasbourg: Bureau of the European Committee on Legal Co-operation (CDCJ-BU).

Poczta-Wajda, A. (2010). Nowoczesne techniki analityczne $w$ kształceniu na studiach ekonomicznych. [Modern analytical techniques of economics studies education]. Poznan: Wydawnictwo Uniwersytetu Ekonomicznego w Poznaniu. 
Raijas, A., Lehtinen, A., Leskinen, J. (2010). OverIndebtedness in the Finnish Consumer Society, Journal of Consumer Policy, 33,209-223.

Russell, H., Maître, B., Donnelly, N. (2011). Financial Exclusion and Over-indebtedness in Irish Households. Social Inclusion Research Report No. 1. Dublin: Department of Community, Equality \& Gaeltacht Affairs and ESRI

Stanisz, A. (2007). Przystępny kurs statystyki $z$ zastosowaniem STATISTICA PL na przykładach $z$ medycyny. T. 3. Analizy wielowymiarowe. [Affordable course of statistics using STATISTICA PL on examples from medicine. T. 3. multidimensional analysis]. Krakow: StatSoft.

Szpringer,W.(2008). Regulacjaupadłościkonsumenckiej. Inspiracje z rozwiązań światowych. [Regulation of consumer bankruptcy. Influences of global solutions]. Wroclaw: Centrum Badań Problemów Prawnych I Ekonomicznych Komunikacji Elektronicznej. Uniwersytet Wrocławski. Available at: http://cbke.prawo.uni.wroc.pl/files/ebiuletyn/ Regulacja_upadlosci.pdf

Świecka, B. (2008). Bankructwagospodarstw domowych. Perspektywa ekonomiczna i społeczna. [Bankrupt households. Economic and social perspective]. Warsaw: Difin.

Świecka, B. (2009). Niewypłacalność gospodarstw domowych. Przyczyny-skutki-przeciwdziałanie. [The insolvency ofhouseholds. The causesconsequences-prevention]. Warsaw: Difin.

\section{Notes}

1 The European Credit Research Institute Deal with analyzing retail financial services in Europe. It was established in 1999 by a consortium of European banking and financial institutions. It is an independent non-profit research institution, developing its operating owing to the cooperation of interdisciplinary teams and networks of academic partners. (www.ecri.be)

2 The European Union Statistics on Income and Living Conditions were first compiled in all EU countries in 2005. EU-SILC is a voluntary, representative survey research of private households, implemented by means of the direct interview technique. The aim of EU-SILC is to provide comparable data for $E U$ countries, concerning their income situation, poverty and other aspects of people's living conditions. Module research on over-indebtedness and financial exclusion was conduced in 2008.

3 The k-means method and statistical program, STATISTICA 9.0, were used. 